\title{
Determining the Tuition Fee per Credit Hour by Learning Experience and Implementation of Activity Based Costing \\ (A Study at A Private University in Bandung)
}

\author{
Elizabeth Tiur Manurung \\ Accounting Department of Economics Faculty \\ Parahyangan Catholic University \\ Bandung, Indonesia \\ eliz@unpar.ac.id \\ Arthur Purboyo \\ Accounting Department of Economics Faculty \\ Parahyangan Catholic University \\ Bandung, Indonesia
}

\author{
Yulia Trinita \\ Accounting Department of Economics Faculty \\ Parahyangan Catholic University \\ Bandung, Indonesia
}

\begin{abstract}
One criteria to achieve the sustainability of a university is when all fund needed can be fulfilled well. And to reach stable university financial is by determining an accurate tuition fee for the students. So then, this research has an objective to determine the Tuition Fee per Credit Hour per Student in a University. Which is used analytical descriptive method, this study found that originally, the university always calculating the tuition fee just by an experience more than 50 years, which is usually based on implementing lower tariff comparing to other universities, and then makes some adjustment with inflation rate every year to year. In order to achieve the right calculation, and learning from an experience year to year, and also to resolve the weaknesses of conventional method, then this study, implement the calculation of Tuition Fee per Credit Hours per Student based on Activity Based Costing (ABC) method. The result of this research, for example from calculating Bahasa Indonesia Subject, the result tariff based on ABC method come up to IDR 165.152,- which was compare to the tariff based on conventional method is IDR 70.000,- this comparison come up to the difference around IDR 95.152,as understated costing, and shows us that university which was implement conventional tariff, actually can't recover an actual expense when Bahasa Indonesia courses have been done in the class. In other words, if all subjects can be adjusted by a correct tariff, then University can avoid fund deficit or can achieve increasing surplus and also their financial performance will increase. Since, University has a financial stability, then sustainability of their operation, also can be achieved.
\end{abstract}

Keywords: Tuition Fee, Activity Based Costing, Accurate Information, Learning Experience

*Notes: This research has been developed based on previous research: "Determining Tuition Fee per Credit Hour based on Modified Activity Based Costing”, has been done for UNPAR Research Department. 2005.

\section{INTRODUCTION}

Financial stability, is one of a dominant factor in Education institution like University to achieve high quality of education, beside other factors likes Human Capital, Infrastructure, and well running system. And sustainability of university can also be achieved if all fund needed can be fulfilled well [1].

Most of University in Bandung, still depends a lot on their Students Tuition fee as their main fund resources. This fact brings University that should be made an accurate calculation of tuition fee. The University wants to know that for each learning process that have been done has produced surplus or deficit. ABC system will provide calculation of tuition fee of teaching and learning process for each subject to determine the surplus or deficit. Activity Based Costing system which is considered one of the method can produce accurate calculation of tariff [2], whereas generally, tariff determination that calculated by educational institution since a long time ago has been just based on conventional 
method or past experiences. Then, based on $\mathrm{ABC}$ system, the university business will be run more efficient, and will make higher surplus.

Since, ABC system can provide more accurate tariff, and can support University management with more accurate information, and from learning the experience of a Private University in Bandung, in calculating Students Tuition fee based on their more than 50 years experience like doing benchmark to other universities, then this study will compared the tuition fee tariff between conventional method and with used ABC system method. Based on those explanation, then the focus of this research are (1) to determine students tuition fee based on university experience/ conventional method; (2) determining students tuition fee based on activity based costing; and (3) to analyze the difference between those tariff.

\section{METHOD}

\section{A. Organizational Learning}

Based on the theoretical frame work, we found that definition of Organizational learning can be elaborated from the model of Simon (1990) as quoted by Collier [3] that is as follow:

Scheme 1 The Model of Relationship between Strategy, Control System, and Organizational Learning [3]

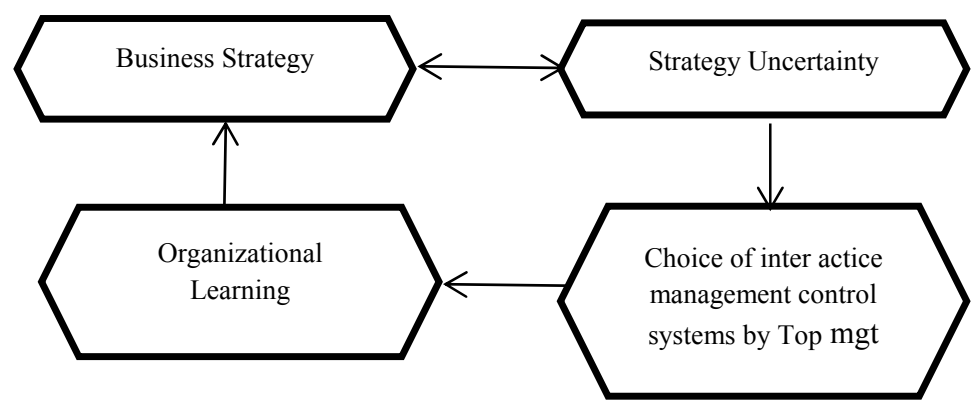

Research by Simon found that the choice by Top Managers to make certain control system interactive provided signal to Organizational participant about what should be monitored and where new ideas should be proposed and tested. This signal activates organizational learning.

\section{B. Activity Based Costing System}

$\mathrm{ABC}$ is defined as costing method that imposes costs on goods, services, or customer based on the use of resources caused by activities such as described by Blocher [2]: "activity based costing is a costing approach that assigns cost to products, service, or customers based on the consumption of resources caused by activities"

We found there are 3 steps to design the implementation of the $\mathrm{ABC}$ system [4] that are: 1) Identify cost that absorbed by the resources and activities based on accounting data which obtained from the company; 2) Charge resources cost on activities, through the selection of the right basic allocation to charge these resources cost in each activity; 3) Charge activity cost on cost objects. Cost object can be goods, services, customer, project, or business unit.

Benefits of $\mathrm{ABC}$ according to Blocher [4] including: 1) Provide information about cost of goods that are more accurate and informative 2) Provide an accurate measurement of activities cost, which can help the managers in increasing value of products and process with better product design decision, better controlling cost, and developing various project that could increase added value; 3) help manager to access cost information which is relevant for decision making. Then, the implementation of $\mathrm{ABC}$ method in calculating tuition fee, it will result a comprehensive and informative cost information, and management can use those information to make relevant decision and develop the learning process.

This study uses analytic descriptive method [5] to observe the 3 statements above. In analytic descriptive, all variables will be explained deeply in a descriptive manner, and also the relationship between phenomena being observed, with analytical scheme ways to give a systematic, factual, and accurate description. While the case study approach is research which focus on a case intensively and detail. In general, case study approach will result a longitudinal description, based on collecting and analyzing data for a certain period of time. Data collections that are used for this approach can be done by observation and interview.

\section{RESULT AND DISCUSSION}

\section{A. Tariff determination in university based on past experiance}

The tariff of Tuition fee per Credit hour, originally was always calculated based on an experience more than 50 years which was usually based on implementing lower tariff comparing to other universities, and then makes some adjustment with inflation rate every year to year, this method we call conventional approach. The weaknesses of the conventional method are that we can't evaluate although the tariff shows right calculation or under stated/ over stated. The result of conventional tariff calculation shows like in table 4 .

But on the contrary, the calculation based on $\mathrm{ABC}$ method [6], the first step in calculating Tuition fee is identifying the Operational variables. And the operating variables in this research object like this university institution are show in table below [7]. 
TABLE I. OPERATIONAL VARIABLES [7]

\begin{tabular}{|c|c|c|c|}
\hline Variable & Dimension & Indicator & Scale \\
\hline 1 & $\begin{array}{l}\text { Data of cost activity } \\
\text { in learning process. }\end{array}$ & $\begin{array}{l}\text { Data of class schedule } \\
\text { and SAP, payroll DT } \\
\text { \& DLB, the } \\
\text { realization of the } \\
\text { purchase and use of } \\
\text { consumables material } \\
\text { and lab equipment, } \\
\text { data of electricity } \\
\text { accounts, spacious } \\
\text { rooms, and budget } \\
\text { realization and rates } \\
\text { of relevant } \\
\text { foundations decree. }\end{array}$ & Ratio \\
\hline 2 & $\begin{array}{l}\text { Costs of learning } \\
\text { process based on } \\
\text { activity. }\end{array}$ & $\begin{array}{l}\text { Method at the rates } \\
\text { generated by activity- } \\
\text { based on cost } \\
\text { calculation. }\end{array}$ & Ratio \\
\hline 3 & $\begin{array}{l}\text { Decision } \\
\text { implementation rates } \\
\text { of S1tuition fee. }\end{array}$ & & \\
\hline
\end{tabular}

The second step is collecting data which is relating to the learning process, and after understanding the sequence of the research conducted and operationalize variables studied, the next data collected can be disclosed such as: Collected data of Class schedule \& SAP each Subject; Data about lab schedule \& study room area; Data about depreciation of buildings per year; Budget and percentage realization (to calculate the allocation of other expenses); Payroll (salaries and structural cost allocation); Data regarding the realization of the laboratory equipment purchasing; Consumables goods are use in laboratory; Electricity bills data; Decree about compulsory teaching hours and structural; Decree about DLB rewards; Electrical equipment in the laboratory; Electrical equipment lecture power halls. And when all data needed was collected properly then the calculation of the cost of the study based on ABC system (modified) can be done, and finally will come-up to the results that are the rates of study costs based activities.

\section{B. Activities related to the learning process}

For ease of explanation on what activities are involved in the learning process, it will be drawn illustration of activities related to learning Bahasa Indonesian subject (3 credits). This course consists of three classes; with teachers generally have functional Lectureship. Then the activities associated with this course are: lecturer class, the use of exclamation/ room using.

Also collect data about Class, land \& building tax of the class itself, electricity cost that has been used in the class, electricity used for in focus for the class, and other indirect cost like cost of Dean \& Vice Dean's salary, indirect cost of head and secretary of the department, and other indirect cost in that department, and also other indirect cost in the unit.
Before calculating the activity based cost for the Bahasa Indonesia class, it needed to describe the calculation formula that will be used, especially the formula for direct and indirect cost for the cost object which is class and courses that listed on this following table.

TABLE II. FORMULA USED IN ACTIVITY BASED COSTING CALCULATION FOR TUITION FEE IN UNIVERSITY [7]

\begin{tabular}{|c|c|c|}
\hline No & Description & Calculation \\
\hline 1 & $\begin{array}{l}\text { Allocation for lecturer's } \\
\text { salary (include lecturer } \\
\text { teaching hours) }\end{array}$ & $\begin{array}{l}\text { Salary each month x (classes } \\
\text { duration (hours) / Lecturer } \\
\text { teaching hours) x } 5 \text { months }\end{array}$ \\
\hline 2 & $\begin{array}{l}\text { If the classes are beyond } \\
\text { the lecturer original } \\
\text { teaching hours }\end{array}$ & $\begin{array}{l}\text { Extra teaching hours x lecturer's } \\
\text { salary overtime per hours }\end{array}$ \\
\hline 3 & $\begin{array}{l}\text { Classes of temporary } \\
\text { lecturer }\end{array}$ & $\begin{array}{l}\text { Teaching hours x temporary } \\
\text { lecturer's rate per hours }\end{array}$ \\
\hline 4 & $\begin{array}{l}\text { Allocation for classes } \\
\text { room depreciation }\end{array}$ & $\begin{array}{l}\text { Depreciation cost building/years } \\
\text { x ( } 14 \text { classes space area } / 35 \\
\text { building space area) } \times 14 \text { courses } \\
\text { time hours / } 840 \text { hours } \\
\text { Ps : } 840=14 \times 6 \times 10 \text { hours }\end{array}$ \\
\hline 5 & $\begin{array}{l}\text { Allocation for } \\
\text { laboratory equipment } \\
\text { depreciation }\end{array}$ & $\begin{array}{l}\text { Based on how many times the } \\
\text { equipment being used }\end{array}$ \\
\hline 6 & $\begin{array}{l}\text { Cost of laboratory } \\
\text { inventory }\end{array}$ & $\begin{array}{l}\text { Inventory spent } x \text { inventory cost } \\
\text { per unit }\end{array}$ \\
\hline 7 & $\begin{array}{l}\text { Allocation for } \\
\text { electricity cost for the } \\
\text { courses }\end{array}$ & Hours based allocation \\
\hline 8 & $\begin{array}{l}\text { Allocation for } \\
\text { electricity cost for the } \\
\text { electrical equipment }\end{array}$ & Hours based allocation \\
\hline 9 & $\begin{array}{l}\text { Allocation for land \& } \\
\text { building tax }\end{array}$ & $\begin{array}{l}\text { Land \& building tax per year } \mathrm{x} \\
14 / 35 \times \text { classes space/ univ total } \\
\text { area } \times 14 / 840\end{array}$ \\
\hline 10 & $\begin{array}{l}\text { Allocation for indirect } \\
\text { cost of the courses : } \\
\text { dean \& vice dean salary } \\
\text { to the classes }\end{array}$ & $\begin{array}{l}\text { Allowance x } 12 \times 14 / 42 \times \text { bahasa } \\
\text { classes hours/total student } \\
\text { learning hours }\end{array}$ \\
\hline 11 & $\begin{array}{l}\text { Average credit unit } \\
\text { taken by the student }\end{array}$ & $\begin{array}{l}\text { (Learning unit taken by the } \\
\text { student per years }+(\text { amount of } \\
\text { student in specific class x class } \\
\text { duration) }) / 2\end{array}$ \\
\hline 12 & $\begin{array}{l}\text { Return to dean \& vice } \\
\text { dean in a form of } \\
\text { allowance }\end{array}$ & $\begin{array}{l}\text { Gross salary per month }- \\
\text { allowance x } 12-x j / 12+ \\
\text { allowance }\end{array}$ \\
\hline 13 & $\begin{array}{l}\text { Allocation for head \& } \\
\text { secretary of the } \\
\text { departments salary to } \\
\text { the classes }\end{array}$ & $\begin{array}{l}\text { Salary x } 12 \times 14 / 42 \times \text { (amount } \\
\text { student in class } \times \text { class duration / } \\
\text { average learning unit taken each } \\
\text { semester) }\end{array}$ \\
\hline 14 & $\begin{array}{l}\text { Return to for head \& } \\
\text { secretary of the } \\
\text { departments in a form } \\
\text { of allowance }\end{array}$ & $\begin{array}{l}\text { Gross salary per month - } \\
\text { allowance x } 12-x j / 12+ \\
\text { allowance }\end{array}$ \\
\hline 15 & $\begin{array}{l}\text { Average learning unit } \\
\text { taken by the student }\end{array}$ & $\begin{array}{l}\text { (Learning unit taken by the } \\
\text { student per years }+(\text { amount of } \\
\text { student in specific class x class } \\
\text { duration) }) / 2\end{array}$ \\
\hline 16 & $\begin{array}{l}\text { Allocation for unit } \\
\text { cost/departments }\end{array}$ & Hour/cost based allocation \\
\hline 17 & $\begin{array}{l}\text { Allocation for other cost } \\
\text { to the courses }\end{array}$ & Hour/cost based allocation \\
\hline
\end{tabular}




\section{The Result of Calculation of Study Cost tariff Based on Activity for Bahasa Indonesia Subject}

Based on all activities related with accomplishment of Bahasa Indonesia subject, here are costs that have counted that absorbed by each activity using the formula in the table above. Therefore, the result of all the calculation will appear in the table like this bellow.

TABLE III. RESULT OF CALCULATION COST OF BAHASA INDONESIA COURSES

\begin{tabular}{|c|c|c|}
\hline No & Activity element costs & Total cost allocation \\
\hline 1. & Lecturers' salaries & IDR 9.100.000 \\
\hline 2. & Equipment amortization & - \\
\hline 3. & Building amortization & IDR 374.623 \\
\hline 4. & Property taxes & IDR 3.081 \\
\hline 5. & Duty electrical load (fixed) & IDR 6.797 \\
\hline 6. & Electricity cost (variable) & IDR 15.846 \\
\hline 7. & $\begin{array}{l}\text { Dean and vice dean's } \\
\text { salaries }\end{array}$ & IDR 282.177 \\
\hline 8. & $\begin{array}{l}\text { Department head and } \\
\text { secretary major's salaries }\end{array}$ & IDR 286.680 \\
\hline 9. & $\begin{array}{l}\text { Other costs in units and } \\
\text { bureaus }\end{array}$ & IDR 4.949.055 \\
\hline 10. & $\begin{array}{l}\text { Other costs in courses or } \\
\text { majors }\end{array}$ & $\begin{array}{ll}\text { IDR } & 4.468 .765\end{array}$ \\
\hline 11. & Total : & IDR 19.487 .942 \\
\hline 12. & Total classes : & Three classes \\
\hline 13. & Cost per class : & IDR 6.495.975 \\
\hline 14. & Student capacity & 45 students \\
\hline 15. & Cost per students & IDR 144.355 \\
\hline 16. & Actual students : & 39 students \\
\hline 17. & Cost per actual students : & IDR 165.152 \\
\hline 18. & $\begin{array}{l}\text { University's cost of the } \\
\text { year: }\end{array}$ & IDR 70.000 \\
\hline
\end{tabular}

Source: the result calculation based on activity method

For clearly of explanation, look to this calculation example: One calculation on table 3 for calculation on cost for other units and bureaus, which is allocated to Bahasa Indonesia courses: is total other costs that happened in units and bureaus which have not allocated to courses for 1 year is IDR 11.172.887.658; average total credits which has taken by all university students at regular semester is 451.520 credits. Other costs that happen in units or bureau which is allocated to Bahasa Indonesia courses $=11.172 .887 .658 \times 14$ meetings $/ 42 \times$ 200 students x 3 hours $/ 451.520=$ IDR 4.949 .055

The tables below will shows also the result of some tariff Tuition Fee per Credit Hour based on ABC method comparing to historical tariff.
TABLE IV. TUITION FEe PER CREDIT HOUR IN ECONOMICS FACUlTy COMPARISON BETWEEN CONVENTIONAL AND ABC TARIFF

\begin{tabular}{|c|c|c|c|}
\hline No & Subject & $\begin{array}{l}\text { Conventional } \\
\text { Tariff } \\
\end{array}$ & ABC Tariff \\
\hline 1 & $\begin{array}{ll}\text { Accounting } & \text { Principles } \\
\text { (EA1.010) } & \\
\end{array}$ & IDR 150.000 & IDR 143.098 \\
\hline 2 & $\begin{array}{ll}\text { Cost } & \text { Accounting } \\
(\text { EA2.041) } & \\
\end{array}$ & IDR 150.000 & IDR 147.875 \\
\hline 3 & Taxes (EA2.070) & IDR 150.000 & $\begin{array}{l}\text { IDR } \\
147.875 \\
\end{array}$ \\
\hline 4 & $\begin{array}{l}\text { Management Accounting } \\
\text { (EA3.021) }\end{array}$ & IDR 150.000 & IDR 147.875 \\
\hline 5 & $\begin{array}{l}\text { Information System } \\
\text { Design (Practical) }\end{array}$ & IDR 70.000 & IDR 172.060 \\
\hline 6 & $\begin{array}{l}\text { Data Based Management } \\
\text { (Practical) }\end{array}$ & IDR 100.000 & $\begin{array}{l}\text { IDR } \\
160.913\end{array}$ \\
\hline 7 & $\begin{array}{l}\text { Information system } \\
\text { (Pract. Computer) }\end{array}$ & IDR 100.000 & IDR 230.371 \\
\hline 8 & $\begin{array}{l}\text { Computer } \\
\text { (Practical) }\end{array}$ & IDR 100.000 & IDR 124.688 \\
\hline 9 & $\begin{array}{ll}\text { Audit } & \text { Computer } \\
\text { Practicum } & \\
\end{array}$ & $\begin{array}{ll}\text { IDR } & 150.000\end{array}$ & $\begin{array}{l}\text { IDR } \\
231.425\end{array}$ \\
\hline 10 & $\begin{array}{ll}\text { Principle } & \text { Accounting } \\
\text { Practicum } & \\
\end{array}$ & 70.000 & 166.503 \\
\hline
\end{tabular}

\section{Analysis the result of calculation about conventional} tariff and $A B C$ tariff

Calculation of each subject based on Activity based costing will come up to more precise result that the full product cost can be calculated if compared to the existing university calculation [8]. This matter can also help establishing a more precise study cost, and also assignment costing to students will be more precise, and then the university can avoid experience understated revenues or can avoid deficit financing.

The university should be more careful in using the data obtained from this expense calculation. Most of the costs that occur in university is indirect costs, so university Board often experience difficulties in choosing the most suitable base allocation to burden indirect costs on final cost object.

Some things other than the obtained cost information based on activities per student that can be considered to help university board in making decisions is to make comparison of study cost tariff to other universities, considering that universities are institution which not only seek for profit purpose, and studies cost that paid by students is not the only source of funds for the university.

In fact the tariff that university set, has not been fully implemented using activity based cost, because leaders have policies that need to be considered, so that still much lower tariff that has been calculated based on this research. For example, tariff like this is the tariff on subjects in unit or faculty that lack of demand.

Information of cost that generated in each subject can be used to help management to set the tariff of studies cost. Using $\mathrm{ABC}$ cost can be seen clearly resource consumption by each subject so the result of full product cost would more accurate. 
As seen in Table (4) above, comparison about the tariff result based on $\mathrm{ABC}$ method and conventional method, it shows us that the University experiencing in more undervalued tariff. These all undervalued tariff will impact in understated revenues, so then if all tariff be recalculated through $\mathrm{ABC}$ method, university will be run their operation more efficient and University surplus will be increased. In other words financial performance of University will be better also.

\section{CONCLUSSION}

The conclusion of this research about "Determining The Tuition Fee per Credit Hour by Learning Experience and Implementation of Activity Based Costing" (A Study at A Private University in Bandung), and with used the analytic descriptive method, conclusion will be described such as: first, The tariff of Tuition fee per Credit hour, originally was always calculated based on an experience more than 50 years which was usually based on implementing lower tariff comparing to other universities, and then makes some adjustment with inflation rate every year to year, this method we call conventional approach. The weaknesses of the conventional method are that we can't evaluate although the tariff shows right calculation or under stated/ over stated. The result of conventional tariff calculation shows like in this table, bellow; secondly, As The University wants to know that for each learning process that have been done has produced surplus or deficit, then this research try to resolve the weaknesses of conventional method with doing recalculate the tariff of tuition fee for each subject based on $\mathrm{ABC}$ method. The result of $\mathrm{ABC}$ system tariff calculation shows like in this table, bellow; thirdly, Since the comparison about the tariff result based on $\mathrm{ABC}$ method and conventional method, shows us that the University experiencing in more undervalued tariff. These all undervalued tariff will impact in understated revenues and actually can't recover an actual expenses, but then if all subject can be adjusted by a correct tariff based on $\mathrm{ABC}$ method, their operation can be run more efficient and University surplus will be increased. In other words Financial performance of University will be better.

\section{References}

[1] [1] D.E. Kieso, J.J. Weygand, \& T.D. Warfield, Intermediate Accounting, USA: John Willey \& Sons, 2013, ISBN 9781118147290 .

[2] S. Holmes, A. Hodgson, \& J. Godfrey, Jayne, 4th edition. Accounting Theory, Australia: John Wiley and Son Ltd, 2013, ISBN 978-0-470-81815-2

[3] P.M. Collier, \& M.Paul, Accounting For Managers: Interpreting Accounting Information for Decision Making 2nd edition, USA: John Wiley. 2006, ISBN 978-0470016091.

[4] E.J Blocher, K.H. Chen, \& T.W. Lin, COST MANAGEMENT A Strategic Emphasis. USA: Irwin McGraw - Hill. 1999, ISBN 9780078025532 .
[5] U. Sekaran, dan R. Bougie, 5th Edition Research Method for Business: A Skill-Building Approach. New York: John Wiley \& Sons Inc, 2010, ISBN 978-0471203667.

[6] R.S. Kaplan, \& R. Cooper, Cost and effect: Using Integrated Cost System to Drive Profitability and Performance. USA: Harvard College. 1998, ISBN 978-0875847887.

[7] A. Purboyo, Arthur, E.T. Manurung \& Y. Trinita; "Calculation of Tuition Fee for S1 and Diploma Students Based on Modified Activity Based Costing", Research Department of UNPAR, Bandung. 2005.

[8] D.R. Hansen \& M.M. Mowen, 5th edition. Cost Management: Accounting and Control, USA: Thomson South Western, 2010, ISBN 978-0324559675. 